\title{
The Route to China: Northern Europe's Arctic. Delusions
}

\author{
BERNARD SALADIN d'ANGLURE*
}

In spite of the mounting Western interest in history, ancient travellers' tales, and historical cartography - brought home to us by the number, quality, and popularity of recent works the arctic regions seem to be peculiarly absent from the mainstream of contemporary historical research. These regions also appear to resist, oddly enough, any attempt at synthesis, as if they can only be understood through a fragmentation of time and space or through the scissions resulting from the disillusionments of a recent past and the stakes placed on future exploitation, over which many different interests are already in confrontation. ${ }^{1}$

\section{GLOBAL AND NATIONAL HISTORY}

I think that this hiatus is not a matter of chance, that it does not spring from the historian's oversight but more from economic, political, ideological, and scientific developments that have taken place in the Christianized West since the Renaissance. These developments have gradually pushed back the unreal in the Western person's mind to make way for "logical thought" and "efficiency", thus creating in the realm of knowledge vast patches of shadow beside those areas of bright illumination. These developments have also led to a historical science whose objectivity has given way to a creed that too often hides the fact that "revolutions" - the appearance of new independent states and the specialization of knowledge - have brought with them a divergence in points of view and a breaking up of geographical representation, notably in the arctic regions. 2 This should not surprise us if we consider that the protagonists of today's science are the antagonists of yesterday in the Arctic, among them the AngloSaxons, French, Dutch, Danes, and Russians, who vied with each other each from their own economic, political, and religious standpoints.

By an easily understood and perhaps even unconscious reflex, the states that today control the real "arctic empires" of Siberia, Alaska, the Canadian North, Greenland and, to a lesser extent, the Scandinavian North - indisputably the last great colonial empires left in the world - seem to try to avoid any global historical perspective that would bring them, in a somewhat less glorious fashion, face to face with the illusions and rivalries that tarnished their beginnings in and appropriations of arctic lands: particularly the illusion of the existence of a northern passage between Europe and China, which would have been an alternative to the known southern routes monopolized by the powerful Iberians.
Is it not a symptom of our era of satellite mapping that the use of the terrestrial globe has become so obsolete that it is now only used by a few specialists or in schools, whereas up to the end of the eighteenth century - when the scientific measuring of longitude at sea was made possible by the portable chronometer - it was considered absolutely indispensable for geographical study, whether the aim was pedagogic, economic, political, religious, or purely scientific? The globe was present in every house, every institution, and on every ocean-going vessel, wherever anyone was interested in acquiring geographical knowledge, either through personal inclination or necessity.

Certainly the information displayed on the terrestrial globe is at the root of innumerable errors and geographical delusions, beginning with those of Christopher Columbus. ${ }^{3} \mathrm{~A}$ globe is a finite space asking to be filled up, and people did not hesitate to do so, even when they had no precise data at hand. But the globe is also an incomparable source for synthesized thought and the only three-dimensional way of looking at the earth's surface that avoids the deformations resulting from the choice of projection or angle imposed by a map on the plane; it is also the only way of making us see the real.importance of the Arctic as an intermediary stage between China and northern Europe. The ill effects of the employment of the "flat map policy", which one has to admit has practical value at the analytical level, can be seen in the present-day splitting up of "learned societies" into their separate entities of Orientalists, Americanists, Africanists, and Oceanists - who no longer know what to do with the arctic regions, and with good reason. ${ }^{4} I$ should, therefore, like to stress the importance of giving back to the globe the role in research and teaching it should never have lost.5

\section{MYTHS AND HISTORY}

An arctic ethnologist is not in the best position to throw light on the shadowy regions of knowledge, since his field of consideration is constantly moving, difficult, and narrow compared with the disciplines of a historian, geographer, cartographer, or specialist of the literature of travel. While the others can make use of the significant progress in the human sciences with regard to documentary sources and the use of new analytical methods applied to them, the ethnologist has to retrogress and maintain a precarious balance between science and nescience, the real and the imaginary, and truth and error, along the frontiers of the other disciplines, while according them all 
an epistemological status. He has to establish a pattern among events, places, prospects, and possibilities from an archaeology of dreams, myths, beliefs, and facts, which in combination have brought forth several centuries of arctic exploration, adventure, representation, and appropriation. ${ }^{6}$

The paradox is that the arctic regions did not exist as a locus for scientific discussion in the stories of voyagers or in cartographical drawings from the time of the Renaissance to the dawn of the twentieth century, when the search for a passage to China gave way to the race for the North Pole. Classical and medieval descriptions of the Arctic and memories of the colonization of Greenland doubtless remained alive and influential for a long time, as we shall see with Mercator, but they no longer had the power to stir people into action compared with the fascination exercised by the search for a northern shortcut to China. The Arctic had become a place of transition - for passing through or just stopping off - an obstacle to explore or to go around, like the more southerly parts of North America and Eurasia. ${ }^{7}$ Was it a promontory of Asia or Europe? Was it a continent or an archipelago? These questions were debated not only in the sixteenth century but still later in the seventeenth and eighteenth centuries, because of the constant search for a passage. ${ }^{8}$

The history of North America and northern Eurasia is more easily understood if looked at from a global and structural viewpoint. The drive toward the east and west, toward an extension of the "frontier", toward the northwest, north, and northeast passages - all take on another sense when isolated from the historiographies tainted with nationalism and looked upon as part of a pattern in East-West relationships, with their economic, political, scientific, ideological, and ontological dimensions, as I have tried to show for the sixteenth century in a recent work. ${ }^{9}$

Most present-day historians agree that after the pioneering days of discovery - from the end of the fifteenth to the beginning of the sixteenth century - explorers such as Cartier, Frobisher, Gilbert, Champlain, Smith, Barents, Davis, Waymouth, Hudson, Button, Munk, Fox, and James were always searching for a direct route to China, though several experts consider this to be an alibi to mask more concrete reasons. In the opinion of other authors the early motives faded very quickly as soon as more accessible resources such as cod, whales, beavers, and tobacco were discovered in regions already explored.

Few people are prepared to admit that faulty maps, errors, and fictive accounts could have played an important role in the organization and execution of voyages of discovery. Modern history, with its liking for certainties - measurable facts and clear social analysis - errs, perhaps, in projecting its reasoning on the past, in setting aside too quickly the mistakes, delusions, and false portrayals that immersed the European elite responsible for commerce, politics, religion, and science. This convention is reinforced by the absence of maps now considered erroneous or imaginary from most contemporary historical atlases. Too rational a reconstruction of the past leads to a danger of misunderstanding it. 10

What then were the Cavelier de la Salle, Bering, La Véren- drye, Middleton and Ellis, Phipps, Lewis and Clark, Chateaubriand, Buchan, Ross, Parry, and Franklin doing in the west, east, and north from the end of the seventeenth to the middle of the nineteenth century, if they were not searching for this famous shortcut?

It would be a delusion to think it was only the adventurers, explorers, and navigators who believed in this myth while the scientific establishment showed more discretion - far from it. There is a long list of cosmographers, cartographers, and geographers who were victims or advocates of the same errors, including some well-known and high-ranking people, such as Mercator, Buache, John Dee, Plancius, Briggs, Champlain, and Moses Pitt. Almost all of them came from northern Europe, and their maps and commentaries had a strong influence on their contemporaries, as evidenced by the insertion of these mistakes in the Grande Encyclopédie of Diderot and d'Alembert." The French Jesuits, some of the best geographers of their time ${ }^{12}$ until the unfortunate suppression of their order, also played an important role in the search for the western route to China.

\section{SCIENCE AND NESCIENCE FROM MERCATOR TO BUACHE}

To illustrate the ambiguous links between science and fiction, we can consider the examples of two maps: one of Mercator's from his atlas of 1595 and the other of Philippe Buache and Joseph Nicolas Delisle, published in 1750. The first (Fig. 1) is remarkable for the precision of its outline, the calculation of the coordinates, and the quality of the projection. Mercator established a new scientific cartography that was to influence generations of cartographers. Yet this same map allies great exactitude with the purest fantasy in reproducing not only the medieval Scandinavian beliefs about the Pole spread by the $I \boldsymbol{n}$ ventio Fortunata toward 1360 (in which a polar maelstrom swirled around a central rock in the middle of four islands partly peopled by pygmies, these islands being separated by currents of water running toward the pole ${ }^{13}-$ the equilibrium between the sea and earth surfaces and the division of the four continents being maintained), but also Zeno's imaginative description with his fictitious islands, such as Frislande to the west of Iceland, an island still depicted in M. Pitt's atlas published in Oxford in 1680 .

The second map is entitled "Carte des nouvelles découvertes au nord de la mer du Sud, tant à l'Est de la Sibérie et du Kamtchatka qu'à l'Ouest de la Nouvelle France' (1750). The Delisle family was distinguished in the service of the king of France from the end of the seventeenth century: Guillaume Delisle became the king's geographer in 1718; one of his brothers went on the great Russian expedition to the north Pacific under Bering but died during it, as did his leader. ${ }^{14}$ It was another brother, Joseph Nicolas Delisle, charged with the organization of Bering's second expedition, who produced this map (Fig. 2) with the help of Philippe Buache, the son-in-law of Guillaume Delisle. They employed the results of the Russian expedition, which came to their family archives. The map was presented at the Academy of Science in Paris and was followed a few years later by the authors' detailed reports on 


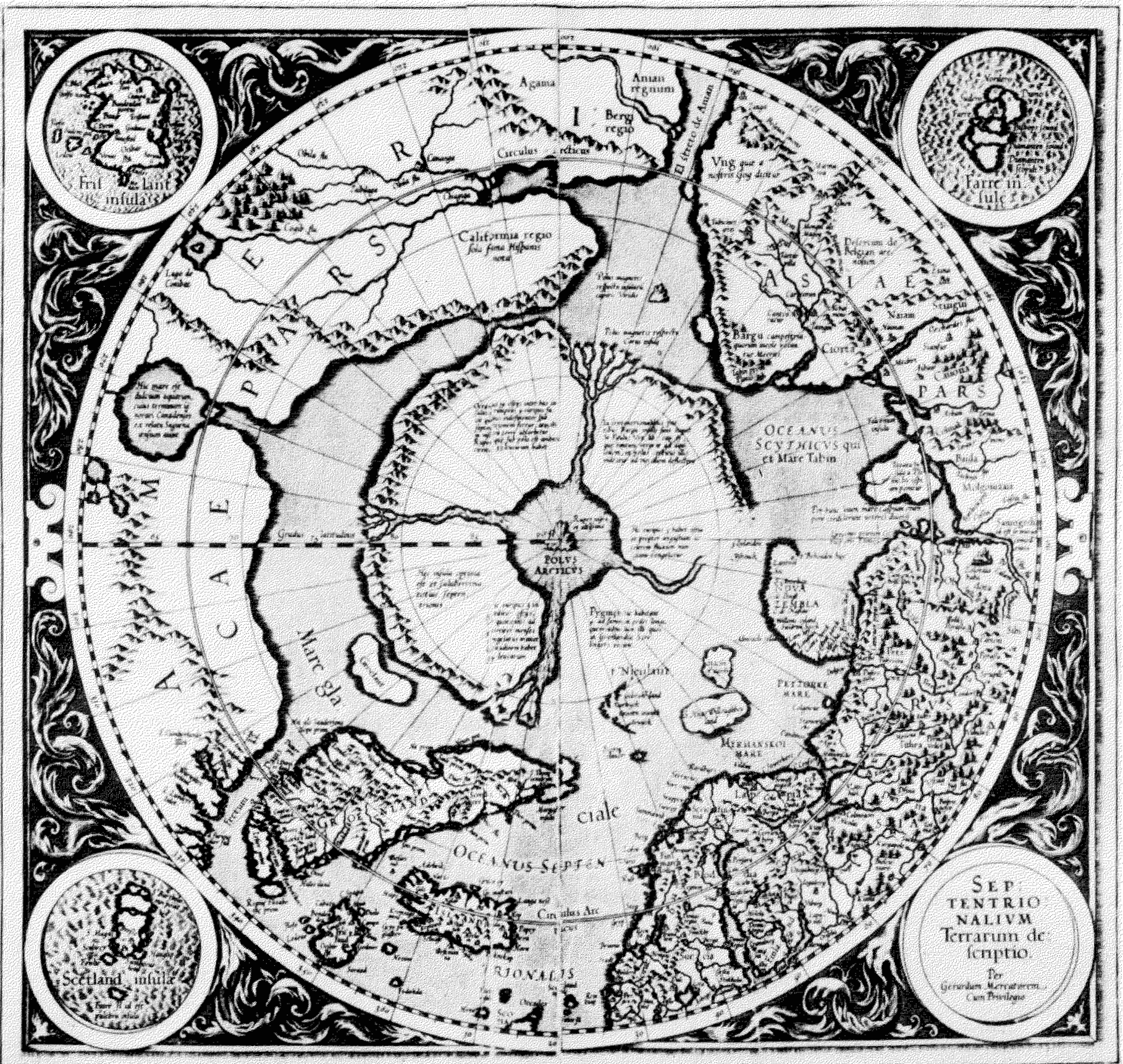

FIG. 1 Gerard Mercator, Septentrionalium terrarum descriptio. Par Gerardum Mercatorem cum privilegio, 1595 . Reproduced from Arctic Images, Public Archives of Canada, 1977.

the northern route to China. ${ }^{15}$ Buache, in his turn, became the king's geographer, then tutor to the royal children and a member of the Academy of Science. He was one of the founders of the science of physical geography through his theory on hydrographic basins. Here again the map itself shows a peak of technical quality in its layout, projection, and coordinates; yet the northwest of America and the Bering Straits are treated in an entirely fanciful manner, with a "west sea" placed between Hudson's Bay and the Rockies, a veritable French mirage brought to life by the revival of the pseudo-discoveries of de Fuca and the outlines of a northwest passage between Baffin Bay and the Pacific, borrowed from the fictitious account of
Admiral de Fonte. ${ }^{16}$ One is surprised today to see with what ease a French geographer of Buache's stature and standing at court - though not particularly scrupulous - was able to enhance his personal prestige with false data and to diffuse these at the highest levels of French science in the middle of the eighteenth century. ${ }^{17}$

\section{HENRY HUDSON SERVES NORTHERN EUROPE AND ITS DELUSIONS}

The exploits of the great explorer Henry Hudson are a good illustration of the great emphasis the countries of northern Europe (England, France, Holland, Denmark, etc.) put on the 


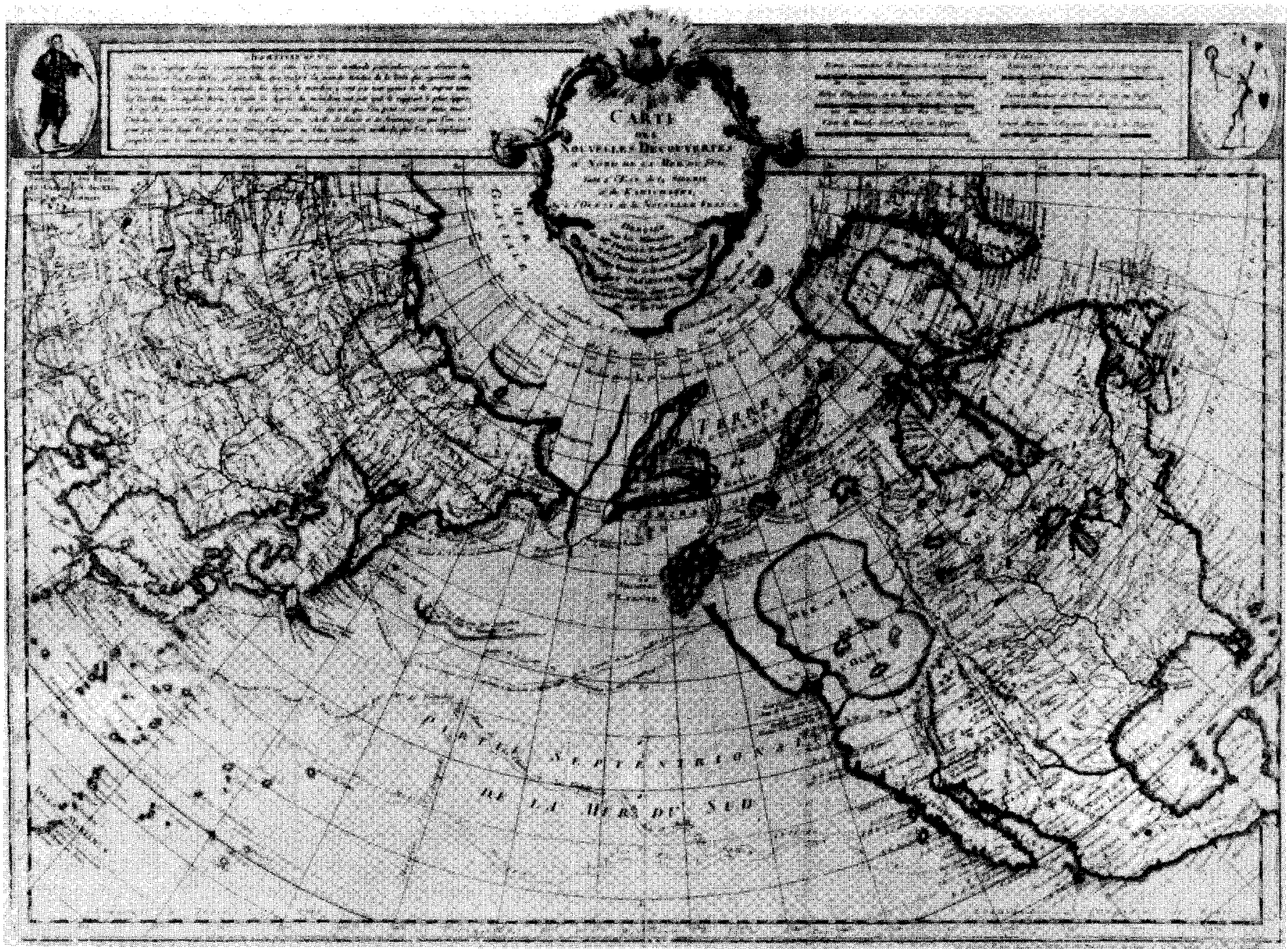

FIG. 2. Joseph Nicolas Delisle and Philippe Buache, Carte des nouvelles découvertes au nord de la mer du sud, tant a l'est de la Siberie et du Kamtchatka, qu'à l'ouest de la Nouvelle France...1750. Reproduced from Arctic Images, Public Archives of Canada, 1977.

discovery of a northern route to China. Hudson searched along every point of the compass calculated as likely, according to the delusions of his epoch, and one after another the big merchant states of the north sounded him out and financed him in an effort to compete with the Iberian trade monopoly in his Indies.

At the dawn of the seventeenth century a fabulous inheritance revealed itself to the bankers, traders, specialists, missionaries, and seafarers - the new pioneers of the Occident a legacy of products, objects, and unknown animals from the Indies to fill the curiosity showcases and royal gardens, a legacy of maps, terrestrial globes, and charts jealously guarded in new commercial companies or religious or royal libraries. It was an inheritance also of delusions, errors, and myths fed by the new discoveries, themselves a mixture of science and alchemy, of experiments and religious beliefs. There was an immense thirst for knowledge and understanding. The fascination of the Orient - so different from the Occident, with another form of society - this harking back to the original source of Paradise Lost and the Infernal Regions, these fabulous riches and terrible scourges flowing in, made northern Europe jealous of the wealth and power of the Iberian and Mediterranean states.
The "bastard" Elizabeth, whose legitimacy the Catholics had contested and whom Pius V, the "inquisitor" pope, had excommunicated and even deposed, had taken her revenge on Spain. Even if she did not have the joy of leaving a new China passage to her country, she certainly left to her successor, James I, an England richer and stronger than ever, with established trading companies, a war-hardened fleet, and new stretches of sea opened by exploration. The England of merchants and sailors under the Stuarts made even more determined efforts to find a route to Cathay. A new generation of seafarers and adventurers was sent out to renew the search.

In the northwest, an Anglo-Danish expedition continued to look for a passage, at the same time searching for traces of the old Scandinavian colony in Greenland. In the west, the hunt for the China route was included in the terms of the charter of the Virginia Company (1606), together with the search for gold and the establishment of a colony.

After religious peace had been restored with the Edict of Nantes, France did not lag behind. It stepped up the search for a possible route through the St. Lawrence, with Champlain playing a great role. The Saguenay River was also considered worth further exploration.

In Holland, which had become the greatest maritime and 
commercial power in Europe, Plancius, the geographer, had just published his "situation of the coasts of Tartary, Cathay and China" (1595) to support explorers in their search for a passage. A reward of 25000 florins was offered to the first person to make the discovery. Barents, another Dutchman, had already died at Novaya Zemlya during an expedition to the northeast, where competition was becoming fierce between the Dutch and English.

At this point the Muscovy Company of London, disappointed by the tragic end of John Knight's expedition to the northwest, became interested in Henry Hudson's project to reach China by the North Pole, believed to be free of ice. ${ }^{18}$ Hudson reached Spitzbergen and discovered a whale-breeding area, but he had to return home on account of the ice. However, his observations led to the Muscovy Company equipping whaling ships in collaboration with Basque fishermen. Hudson was sent out again the following year by the company to profit from Barents's discoveries in the northeast, but he could not get beyond Novaya Zemlya and returned once more to England, to the disappointment and dwindling interest of his backers.

He therefore left for Amsterdam, where he received a great deal of attention. He was offered employment by the recently formed Dutch East India Company to continue the explorations ended by the death of Barents. Hudson met Plancius, who showed him Waymouth's log book, and he received letters and a map indicating a possible passage to China north of the state of Virginia ${ }^{19}$ from his friend Smith, the governor of that state (1608). In Amsterdam he also made the acquaintance of Isaac Le Maire, a rich shipowner of French Huguenot origin who shared secretly in the founding (1609) of the Compagnie française du Pôle Arctique. ${ }^{20}$ Le Maire tried to engage Hudson to lead an expedition to Cathay via the northeast on behalf of this company. Henry IV and Sully, when informed of this secret project, supported it enthusiastically and participated in its financing. However, the negotiations took time and the Dutch signed a contract with Hudson in the meantime.

Hudson nevertheless agreed, unknown to his partners, to offer help and advice to the French. The French company bought a ship behind the cloak of Le Maire, which was to sail under Dutch colours to avoid attention but was to continue under the French flag if successful. Henry IV offered a prize of $£ 25000$ to the leader of the expedition if successful and was graciously prepared to give his name to the straits commanding the entrance to the passage. ${ }^{21}$ There was great confidence in Paris in the successful outcome of this expedition, which was placed under the leadership of Kerckoven. Plans were outlined for the occupation of the "passage": two forts were to be built, one on each side, to control its use; the French flag would be imposed; and goods passing through would be subject to a four percent tax. ${ }^{22}$ The voyage out and back to Cathay was estimated at six months, while the Portuguese and Spaniards took at least two to three years. The ship was to go to China, if possible, and then on to Japan and the Moluccas. The ship actually left Holland a few days after Hudson and followed him as far as Novaya Zemlya, where an impenetrable mass of ice forced it to turn back.
Hudson managed to persuade his crew to sail for North America to explore the new channel recently found by his friend Smith. They sailed along the coasts of New England and on 11 September 1609 entered a river (New York Bay) that they named North River (now the Hudson River). They sailed up it for ten days, fishing and bartering for furs with the native inhabitants, until they were satisfied the river did not lead to a passage. (On 30 July, a month earlier, only a few days' march from this spot, Champlain had inflicted a crushing defeat on an Iroquois tribe in the course of his search for a route, but he had set out from the St. Lawrence basin.) Hudson brought back his observations and the results of his bartering to Amsterdam, which a few years later led to the founding of a flourishing fur trade and the installation of a new Dutch colony, the New Netherlands, with New Amsterdam (the future New York) as its capital.

The year 1609 was auspicious for the Dutch. They obtained a truce with Spain, and with it unofficial recognition of their independence, and they founded the Bank of Amsterdam. A number of territories in Asia and Africa had been taken from the Portuguese by force, and it was now their intention to be the first to discover the northern route to the Far East. In the meantime, they meant to play their part in the new lands discovered in the north and west, as did the English already newly settled in Virginia and the French in New France. ${ }^{23}$ These three countries now had their own India companies and openly disputed the hegemony of Spain and Portugal.

In this atmosphere of competition, rivalry, and excitement, each attempted to retain the services of the most experienced navigators as well as the least bit of information. Hudson had hardly returned from North America when he was forbidden to work for any other country by the English authorities. An English company for the Northwest Passage placed the conduct of another expedition under Hudson, who left Gravesend on 17 April 1610 in the Discovery, a ship that had already served Waymouth and was to become famous in several later voyages.

A victim of mutiny and the dreams and delusions of his contemporaries, Hudson disappeared into the arctic mists of the bay that now bears his name. For another three centuries the northern countries continued to pursue this myth of power and riches to be found in the Paradise Lost on the other side of the world.

\section{NOTES}

'The recent fine work of R. Boyer et al. (1981) on the North Sea and the Baltic should, however, be cited.

${ }^{2}$ Without wishing to overvalue Western historical perspectives before the great revolutions (which took place from the end of the eighteenth century), perspectives too often tainted by Eurocentrism, one can find therein a wider approach better able to account for the links between the West and the rest of the world (as is the case in the work of Raynal and d'Alembert on the European settlements of the two Indies, 1770) than in the much narrower and nationalistic approaches that followed. ${ }^{3}$ Some very interesting recent work on Christopher Columbus shows to what extent the transposition of Marco Polo's data onto a terrestrial globe, exaggerating the dimensions of Asia, could have given him the 
mistaken idea that the route to India and Cathay was shorter by the west.

${ }^{4} \mathrm{Cf}$. the critical work on Orientalism published by E. Said (1980), although the author only deals in detail with the connections between the West and Islam in the nineteenth and twentieth centuries.

SAn importance that should be given back not only to recent globes, with their benefit of the most up-to-date research, but also to historical globes as a means of studying past representations. $C f$. Randles (1980).

6Michel de Certeau (1975) has brilliantly raised the epistemological problems posed by the practice and writing of history, after R. Barthes (1967), P. Veyne (1971), Moscovici (1968), and Foucault (1969).

7That is to say the continental masses of what are actually Canada, the United States, and the Soviet Union. An amusing anecdote well illustrates this nonexistence of the Arctic and the contagion of false descriptions. Martin Frobisher thought he had brought back an authentic Tartar or Samoyede from his first voyage to the bay now named after him, which he took for the passage separating Asia in the north from America in the south. The native was therefore greeted as an Asian on arrival in London, and if we believe Kirwan (1961), shortly afterward Ivan the Terrible's ambassador made a formal protest to the Queen of England against the kidnapping of one of the tsar's subjects by the English explorer - the poor Inuk died soon after anyway.

II was, in fact, the voyages of Bering and, above all, of Cook that established the existence of the Bering Strait; hence the insularity of the American continent. One has to wait until the great polar expeditions of the nineteenth century for precision and certainty with regard to the configuration of the Arctic.

?Cf. B. Saladin d'Anglure (1980), where the comparison of the stories of the voyages, geographical maps, and terrestrial globes with the beliefs inherited from the Middle Ages and the great novels, such as those of More and Rabelais, brings out the important ontological dimension in the motivation of the voyagers and their monied supporters during the Renaissance.

${ }^{10} \mathrm{Cf}$. M. de Certeau (1975) and some other recent works of the great representatives of French historiography, such as Ariès, Duby, Furet, Le Goff, and Leroy Ladurie, who try to reintroduce the imaginary into the field of history.

"It would be interesting to examine the close relations between the pioneers of exploration and the scientific cartography of the French encyclopedists in the second half of the eighteenth century. We know from Chateaubriand's Mémoires d'Outre-tombe that it was Malesherbes, the protector of the encyclopedists, who encouraged him and helped prepare his voyage to discover the Northwest Passage in the New World. Besides, d'Alembert kept up a correspondence with Phipps about the polar route to China ( $c f$. Savours's paper, this volume), and the cartographer of the encyclopedia was a disciple of Buache.

12The Jesuit idea of a link between China and the West appeared clearly in a great number of texts and testimonies from the beginning of the seventeenth century. The Jesuits had the great advantage of being already implanted in China, and their influence, as much over French political power in the seventeenth century as over the colony in New France, was no stranger to the great push toward the west, northwest, and southwest in the French expansion in North America. It is probable that the great moral defeat inflicted on the order after the quarrel over the "rites" was a prelude to its suppression (in France, 1764; in Rome, 1773 - the expression of the total loss of political power in the Occident). It coincides, curiously, with the Treaty of Paris, which lost Canada to England definitively. Scientific and encyclopedic ideology, anti-Jesuit and anti-colonialist, took up, in turn, the myths about the Orient and the shorter ways of getting there-a geographical shortcut, such as the northern passages, and a symbolic shortcut, such as the Grand Orient freemasons, with their rites of passage, which, starting with England, took on a growing importance in French political and intellectual life.

13From the Middle Ages to the middle of the nineteenth century the belief in a warm polar sea, free of ice, remained deep-rooted. The existence of sea areas free of ice, such as that of Smith Strait, northwest of Greenland, helped to foster this illusion. One should also remember the tradition of a polar maelstrom, which gave rise to a strange account published anonymously in Paris in 1721 called "Le Passage du Pôle Arctique au Pôle Antarctique par le Centre du Monde", a theme used since by several authors in fiction. For a commentary on this account see C. Verner and B. Stuart-Stubbs (1979).

${ }^{14}$ This was Louis Delisle de la Croyere, who, like Bering, died of scurvy in the Kamchatka region on the way back with the 1741 expedition.

15In particular that of Buache (1753).

${ }^{16}$ Another Buache, J.N. Buache de la Neuville, a nephew and disciple of the former, was an ardent defender of the work and ideas of his uncle until his death in 1825 . Holder of a professorial chair in the Ecole Normale Supérieure (1794) and a member of the institute, it was he, as the chief naval hydrographer, who drew up the geographical nautical instructions in 1785 for the expedition of La Pérouse. In these instructions he quotes De Fuca and De Fonte as sources worthy of credit. $C f$. M. Emmanuel (1959).

${ }^{17}$ Cf. M. Emmanuel (1959) and N. Broc $(1969,1980)$ for detailed presentations of these discoveries and fanciful accounts, as well as N.M. Crouse (1928) and Williams (1962).

${ }^{18}$ See the commentary of Verner and Stuart-Stubbs.

${ }^{19} \mathrm{Cf}$. W.P. Cumming et al. (1959).

${ }^{20} \mathrm{Cf}$. Ch. de La Roncière (1907) and M. Emmanuel (1959).

${ }^{21}$ As Magellan gave his to the straits that he discovered in the southwest.

${ }^{22}$ A similar tax was imposed by the Danes on all merchandise crossing the sound, which made their fortunes.

${ }^{23}$ Québec had been founded in 1608 by. Champlain

\section{REFERENCES}

AMSLER, J. 1960. Histoire universelle des explorations. Vol. 2. La Renaissance 1415-1600. Paris: Sous la direction de L.H. Parias.

BARTHES, R. 1967. Le Discours de l'histoire.' Social Science Information VI(4):65-75.

BOYER, R., JEANNIN, P., and GRAVIER, M. 1981. Mer du Nord et Baltique. Paris: Arts et Métiers graphiques.

BROC, N. 1969. Les montagnes vues par les géographes et les naturalistes de langue française au XVIIIle siecle. Ministère de l'Education nationale, Comité des travaux historiques et scientifiques. Mémoires de la section de géographie 4. Paris: Bibliothèque nationale.

1980. La gégraphie de la Renaissance (1420-1620). Mémoires de la section de Géographie. 9. Paris:-Bibliotheque nationale.

BUACHE, P. 1753. Considérations. géographiques et physiques sur les nouvelles découvertes au nord de la grande mer, appelée vulgairement La Mer du Sud. Paris.

CERTEAU, M. de. 1975. L'écriture de l'histoire. Paris: Editions Gallimard.

CHARLIAT, P.J.. 1957. Histoire universelle des explorations. Vol. 3. Le temps des grands voiliers. Paris: Sous la direction de L.H. Parias.

CHATEAUBRIAND, F. de. 1899. Les Mémoires d'Outre-tombe. Paris.

CROUSE, N.M. 1928. In the Quest of the Western Ocean. London: J.M Dent and Sons Ltd.

CUMMING, W.P., SKELTON, R.A., and QUINN, D.B. 1972. The Discovery of North America. London: P. Elek, Ltd. [French transl: La découverte de I'Amerique du Nord. Ouvaroff, Jet S. (trans.) Paris: Albin Michel.]

DAINVILLE, F. de. 1940. La géographie des Humanistes. Paris.

DELANGLEZ, J. 1947. A Mirage: the Sea of the West. Revue d'histoire de l'Amérique française 1(3):346-381. 
DIDEROT, D., and D'ALEMBERT, Le Rond. 1751-72. Encyclopédie ou Dictionnaire raisonné des Sciences, des Arts et des Métiers. 17 vol. de texte et 11 vol. de planches. Paris.

DELISLE, J.N., and BUACHE, P. 1750. Carte des nouvelles découvertes au nord de la Mer du Sud, tant à l'est de la Sibérie et du Kamtchatka qu'a l'ouest de la Nouvelle-France. Paris.

EMMANUEL, M. 1959. La France et l'exploration polaire. Vol. 1. De Verrazzano a La Pérouse 1523-1788. Paris: Nouvelle Editions latines.

FOUCAULT, M. 1969. L'archeologie du savoir. Paris: Gallimard.

KIRWAN, L.P. 1961. Histoire des explorations polaires des Vikings à Fuchs. (Transl. from English by J. Jouan). Paris: Payot.

LA RONCIERE, C. de. 1907. Les premières explorations françaises aux Pôles. Journal des savants 5 :

MOSCOVICI, S. 1968. Essai dur l'histoire humaine de la nature. Paris: Flammarion.

PLANCIUS, P. 1595. Situation des côtes de Tartarie, du Cathay et de la Chine.

RANDLES, W.G.L. 1980. De la terre plate au globe terrestre: une mutation épistémologique rapide, 1480-1520. Cahier des Annales 38. 120 p.

RAYNAL, G. 1770. Histoire philosophique et politique des établissements et du commerce des Européens dans les deux Indes. 7 vols. Paris.

SAID, E. L'orientalisme. L'orient créé par l'occident. (Transl: from English by C. Malamoud). Paris: Seuil.

SALADIN D'ANGLURE, B. 1980 . Le syndrome chinois de l'Europe nordique ou la démesure de l'Amerasie entre le temps de l'Astrolabe (1480) et l'espace du chronomètre (1780). L'Ethnographie 76(81-82).

VERNER, C., and STUART-STUBBS, B. 1979. The North Part of America. Toronto: Academic Press.

VEYNE, P. 1971. Comment on écrit l'histoire. Paris: Seuil.

WILLIAMS. 1962: The British Search for the Northwest Passage in the Eighteenth Century. London: Royal Commonwealth Society Imperial Studies 24. 